\title{
Lumen
}

Selected Proceedings from the Canadian Society for Eighteenth-Century Studies

\section{Contributors Collaborateurs}

Volume 24, 2005

URI : https://id.erudit.org/iderudit/1012183ar

DOI : https://doi.org/10.7202/1012183ar

Aller au sommaire du numéro

\section{Éditeur(s)}

Canadian Society for Eighteenth-Century Studies / Société canadienne d'étude du dix-huitième siècle

ISSN

1209-3696 (imprimé)

1927-8284 (numérique)

Découvrir la revue

Citer ce document

(2005). Contributors / Collaborateurs. Lumen, 24, 173-174.

https://doi.org/10.7202/1012183ar

Copyright @ Canadian Society for Eighteenth-Century Studies / Société canadienne d'étude du dix-huitième siècle, 2005
Ce document est protégé par la loi sur le droit d'auteur. L'utilisation des services d'Érudit (y compris la reproduction) est assujettie à sa politique d'utilisation que vous pouvez consulter en ligne.

https://apropos.erudit.org/fr/usagers/politique-dutilisation/
Cet article est diffusé et préservé par Érudit.

Érudit est un consortium interuniversitaire sans but lucratif composé de l’Université de Montréal, l'Université Laval et l'Université du Québec à Montréal. Il a pour mission la promotion et la valorisation de la recherche. https://www.erudit.org/fr/ 


\section{Contributors / Collaborateurs}

Pierre Berthiaume, Professeur titulaire au Départment des lettres françaises de l'Université d'Ottawa, est spécialiste de la littérature du XVIII ${ }^{e}$ siècle (roman, littérature d'idées et littérature de voyage).

Marie-Hélène Chabut is Professor of French at Lehigh University. She is author of Denis Diderot. Extravagance et génialité (1998). In recent years, her research has focused on women writers, especially Isabelle de Charrière. She is presently working on a book on Charrière's "reading" of the French Enlightenment.

Beatriz de Alba-Koch is Associate Professor of Hispanic literature at the University of Victoria. She was educated at ITESM, Paris III, Queen's, and Princeton universities. She has published a monograph as well as several articles on Fernández de Lizardi, and is completing a study dedicated to his La Quijotita y su prima. Other publications have explored the works of Sor Juana, Sigüenza y Góngora, Clavijero, Guridi y Alcocer, and Altamirano.

Frans De Bruyn is Professor of English literature at the University of Ottawa. He is currently engaged in a study of eighteenth-century agricultural writing and its relation to the larger literary culture of the period.

Catherine Gallouët, Chaire du Département de français et d'études francophones de Hobart \& William Smith Colleges, a publié un livre (Marivaux. Journaux et fictions, Orléans, Paradigme, 2001) et de nombreux articles sur le roman au XVIII ${ }^{\mathrm{e}}$ siècle. Ses recherches actuelles portent sur le texte de l'autre.

Nicholas Hudson, Professor of English at the University of British Columbia, is the author of Samuel Johnson and Eighteenth-Century Thought (1988), Writing and European Thought, 1600-1830 (1994), Samuel Johnson and the Making of Modern England (2003), and of numerous essays on eighteenth-century literature, thought, and culture. 
Kathryn James completed her master's and doctorate in British history and the history of medicine at Oxford University. She works as an instructor and curriculum developer at Everett Community College.

Laurence Mall est Professeure agrégée de littérature française à l'Université d'Illinois (Urbana-Champaign). Elle est l'auteure de deux ouvrages sur Rousseau, Origines et retraites dans La Nouvelle Héloïse (1997) et Emile ou les figures de la fiction (2002) ainsi que de divers articles sur la littérature française. Elle travaille actuellement sur l'éthique de Diderot et sur les Tableau de Paris de Mercier.

Robert Merrett is Professor of English at the University of Alberta and Vice President (Development) of the Canadian Federation for the Humanities and Social Sciences/ Fédération canadienne des sciences humaines in Ottawa. Current book projects include the preparation of a volume on food and cultural history in eighteenth-century Europe and another on the relations between French wine and British literary history.

Mitia Rioux-Beaulne rédige actuellement une thèse de doctorat en philosophie à l'Université de Montréal sur la pensée de Diderot.

Lauren Craig Stephen is a PhD Candidate at McMaster University. His research examines how eighteenth-century ideas and writing about sexuality and animals serve to create and reinforce powerful taxonomies for social control, including categories such as 'human,' 'nature,' 'gender,' and 'perversion.'

Servanne Woodward est Professeur à l'Université Western Ontario, où elle enseigne des cours sur le XVIII ${ }^{\mathrm{e}}$ siècle français, la théorie coloniale et post-coloniale, et les auteurs féminins. 